\title{
Complexity Relationship between Power and Trust in Hybrid Megaproject Governance: The Structural Equation Modelling Approach
}

\author{
Binchao Deng (D), Wenwen Xie, Fan Cheng, Jiaojiao Deng, and Liang Long \\ School of Management, Tianjin University of Technology, Tianjin 300384, China \\ Correspondence should be addressed to Binchao Deng; dbchao1985@tju.edu.cn
}

Received 13 September 2020; Revised 4 November 2020; Accepted 21 January 2021; Published 8 February 2021

Academic Editor: Guangdong Wu

Copyright ( 2021 Binchao Deng et al. This is an open access article distributed under the Creative Commons Attribution License, which permits unrestricted use, distribution, and reproduction in any medium, provided the original work is properly cited.

\begin{abstract}
Intra-organization and inter-organization collaboration and governance are becoming increasingly important for megaprojects. Different stakeholders form intricate links in a network structure. This study explores the role and effect of hybrid governance on complex network projects, such as urban rail transit projects. This included conducting a questionnaire survey with 116 professionals from organizations involved in urban rail transit projects and adopting structural equation modelling to analyze the data. The results analyzed the levels of intra-organization and inter-organization trust under the conditions of power asymmetry and power sharing. A higher level of power asymmetry was associated with lower hybrid governance performance. In contrast, a higher level of power sharing is associated with better hybrid governance performance. The results are generalizable to other projects with complicated organizational and network relationships.
\end{abstract}

\section{Introduction}

Megaprojects are often defined as projects with budgets over $\$ 1$ billion with extreme technical and organizational complexity, a long time span, and a large number of stakeholders [1-4]. They usually refer to large public projects having a profound impact on politics, the economy, and public life in their locations $[5,6]$. Because of these megaprojects' characteristics, $90 \%$ of the world's megaprojects have the problems of cost overruns and schedule delays [7]. Examples include the Beijing Olympic Stadium project (nicknamed Bird's Nest) $[8,9]$, South African public sector megaprojects [10], and the Sydney Opera House [11]. This highlights the importance of analyzing the factors affecting project governance performance and project success.

Megaprojects are temporary endeavors (i.e., projects) characterized by large investment commitments, vast complexity (especially in organizational terms), and longlasting impact on the economy, the environment, and the society [12]. Megaprojects are typically hybrid organizations (intra-organization and inter-organization), built by relevant stakeholders (owner, designer, contractor, supervisor, etc.) through market-oriented contracting. The mutual benefits of power asymmetry and power sharing based on intra-organizational and inter-organizational trust levels should create an efficient and harmonious working environment, resulting in improved project performance. However, self-centered behavior of bounded rationality, moral hazard, and opportunism may lead to conflicts that affect project performance $[13,14]$.

Generally, addressing project performance issues centers around organizational factors [15], environmental factors [16], institutional factors [17], contracts and tendering [18], project planning and scheduling $[19,20]$, and leadership and bounded rationality $[21,22]$. Previous studies have often adopted a deterministic approach to identify the influencing factors in different governance structures that promote megaproject performance $[15,16,23,24]$. A megaproject is a typically complex organization, with a hybrid structure described by $[25,26]$. This highlights the need to analyze and explain the objectives of different interests, management, governance structure, behaviors, and strategies of 
stakeholders in mixed organizations. It is important to assess multiple partners in this process, examining both horizontal and vertical interplay in megaproject hybrid governance. This includes the horizontal contract governance between the owner and the general contractor. It also includes the vertical corporate governance within the internal organization of the general contractor [27].

Hybrid governance has become a common term in political, economic, and management literature $[25,26,28,29,30]$; however, its definition remains amorphous and its use inconsistent. Power and trust are key factors influencing project performance [31, 32]. Variations in the scope and the scale of perspectives on hybrid governance somewhat limit the ability of researchers to further develop and test theory. This study addressed some of the conceptual limitations associated with studying hybrid governance in megaprojects, such as transportation, airports, nuclear power plants, and other major infrastructure assets. Specifically, the study focused on the networks of both vertical and horizontal relationships in megaprojects, with hypotheses related to the mutual influence of power-trustperformance. (1) The study evaluated the horizontal interplay of contract governance, which has benefits from and for the owner and the general contractor. (2) The study evaluated the vertical interplay of corporate governance within the general contractor organization and its departments. Those hybrid organizations were divided into two parts: horizontal and vertical.

This study applied a questionnaire survey approach to collect data from urban rail transit projects in six cities in China. The data were then analyzed using partial structural equation modelling (SEM). The next section of this paper provides the theoretical background of power asymmetry and power sharing, intra-organization and inter-organization of trust levels, and hybrid governance performance. Finally, this paper presents a clear interactional path of power-trust-performance for megaproject stakeholders, addressing specific aspects of conflict and methods for mitigating them to achieve the better performance with international construction projects.

\section{Related Theories and Hypotheses Development}

This section reviews the governance literature and principalagent theory as a foundation for discussing the assignment of accountability to achieve benefits. It then applies the powertrust-risk approach to establish appropriate management approaches for hybrid governance performance and proposes a series of research hypotheses.

2.1. Hybrid Governance. The project governance landscape has changed considerably over the last few decades [33-35]. These changes have resulted from bounded rationality, contract incompleteness, information asymmetry, and integrity levels inside and outside megaproject organizations. The project governance reforms that have occurred over the years can be broadly classified in two domains: changes in the internal governance mechanisms of organizations and transitions in the external governance pressures [36-38]. Internal mechanisms broadly include an effectively temporary organizational structure established through a market contract. This includes the value system, responsibilities, processes, and policies that allow projects to achieve organizational objectives and foster implementation using approaches that serve the best interests of all the stakeholders [33]. Changes have also been imposed by those outside the organization, including governments, financial institutions, and regulators, through new guidelines and laws [39]. Project governance is widely recognized as a critical factor for successfully delivering projects and achieving their benefits [40]. However, in entering market contracts, owners and contractors enter an inherently complex organizational form and alliance in a megaproject. This recognition has spurred public and scholarly interest in extending project governance. Hybrid governance is one development of project governance in the construction field.

Hybrid governance originates from Williamson's [26] research, who combined institutional economics with aspects of contract law and organization theory to identify and explain key differences between three generic forms for organization-market, hybrid, and hierarchy. Williamson clarified that each generic form is supported and defined by a distinctive type of contract law, which benefits from the analysis and development of transaction cost economics [26]. This was built on research from the 1930s, when Coase proposed a "market-enterprise" dichotomy in two kinds of organizations; the dichotomy coordinates economic activities. Researchers have applied the concept of "Institutional Structure of Production" to analyze different complex organizational forms. Asset specificity and transaction uncertainty are key factors that determine the organizational governance structure [41]. With the continuous progress of science and technology that has deepened globalization, there has been a steady increase in the degree of asset specificity and transaction uncertainty. This has increased the risk of opportunism that leads to traditional organizations facing higher and higher transaction costs $[42,43]$.

To mitigate risks of opportunism and moral hazard that are inherent in inter-organizational or intra-organizational coordination, different governance structures should be selected in different organizations. This is particularly true for complex transactions that require co-creation, which is often the case in the construction industry [44]. This also requires a transitional governance structure between market governance and hierarchy governance; this structure is hybrid governance, due to the specific difference between asset specificity and transaction uncertainty. Contracting parties are more likely to form such hybrid organizations in megaprojects, using a hybrid organization described by [28].

Hybrid governance research has found widespread practices in mixed organizations composed of different stakeholders [45, 46], including public-private partnerships [47, 48], multiagent alliances or partnerships [49], social enterprises [50], and nonprofit networks [46]. The principalagent relationship in hybrid organizations reveals common interests and inherent conflicts between the two entities [51]. 
Potential conflicts of interest exist between project participants because they all have their own interests. Previous principal-agent research has been successfully applied to research construction project management $[52,53]$. As such, the regulation and incentives driving stakeholders (owner as principal, the contractor as agent, and their subcontractors) have become a research focus in megaproject organizations.

There are many opportunities to apply and translate project governance research in the construction field to other organizational forms. This study applied hybrid governance research to hybrid organizations in megaprojects, opening up new avenues for research, practice, and policy. Furthermore, the study combined contract and corporate governance within the hybrid organization of a megaproject to help link hybrid governance structure to power and trust in project contexts, advancing our theoretical and practical understanding of megaproject governance. The hybrid governance structure can be divided into contract governance and corporate governance. In other words, the contract-corporate structure is a binary structure in hybrid governance (see Figure 1).

Figure 1 shows three interactive relationships among the owner, the general contractor, and the department $i$ of the general contractor. These are all parts of a mixed governance structure in megaproject processes. The general contractor may have several departments, $1<i<n$, including design, construction, and management. First, the contract governance in intra-megaproject organizations is derived from the construction contract signed by owner and contractor. The construction contract defines the rights, responsibilities, and obligations between owner and contractors. Second, the corporate governance in an inter-megaproject organization comes from the arrangement of the internal institutional management system of the general contractor, which is a group company. Third, oversight is exercised through the signed construction contract, which means that owners participate in the inspection and acceptance process, project schedule, quality inspection, and project assessment.

Based on these three relationships of management and governance, problems occur in the life cycle of project processes, including cost overruns, project delays, quality problems, and unreasonable risk allocation [54-57]. These are rooted in information asymmetry and incompleteness, bounded rationality of the participants, and uncertainty. All of these can lead to power asymmetry and different trust levels. In the construction practice, good risk transfers or risk allocations are a way to influence project governance performance $[58,59]$. However, the combination of uncoordinated cooperative relationships, incomplete contracts, and risks that fall beyond the contractor's capacity fails to advance improvements in project management or governance performance. Instead, it increases the risk reversal from the contractor to owner, ultimately reducing project performance. In a hybrid governance structure in a intra/ inter-megaproject organization, the degree of power asymmetry and trust levels should remain a key focus of governance. Past studies have made significant contributions in understanding power and trust in governance areas (contract, corporate, project, relationship, etc.) over the years; however, research gaps and limitations remain in the project governance domain.

2.2. Power and Trust in Project Governance. Power and trust are two important factors in internal and external organizations relationships in different governance areas [60-62]. They play a particularly important role in project governance. The paramount epistemological question concerning power and/or trust is whether or not to control and/or trust someone or something. Power and trust inherently involve risk; eliminating risk also eliminates the need for power and trust. In a hybrid governance perspective, projects as temporary organizational forms deserve special attention with respect to the coordinating role of power and trust. Thus, literature reviews will be separated into power and trust under the perspective of project governance..

2.2.1. Power in Project Governance. The Cambridge English Dictionary defines power as the ability to control people and events. Emerson [63] described power as a property of a relationship. Essentially, power can control, influence, or change the behaviors of others [64]. Power can be also understood as manipulating others' desires, attitudes, and behaviors through social structure and cultural patterns [65]. Using market-oriented contracts in the early stage of the megaproject, the owner and contractor establish a cooperative organization, which is characterized by large-scale investments, a long life cycle, and technological and environmental complexity [4]. The governance of megaprojects is a typical complex system that leverages hybrid governance to address chaos, conflict, relevance, and hybrid complexities. The term "hybrid governance" is used in this section to refer to processes that seek to share power in decision making with the owner and contractors to develop shared recommendations for effective, lasting solutions to project problems, including changes and price adjustments. All of these are part of the life cycle megaproject management or governance.

Prior research has identified two primary concerns about power in intra-organizational and inter-organizational governance: convening stakeholders and managing power imbalances. First, corporate or organization reputation is impacted by the preferences of powerful stakeholders [66]; however, the megaproject owner often acts as both a convener and participant in a collaborative or governance process. This raises questions about the owner's ability to dominate or control risk in a life cycle execution system or governance structure $[67,68]$. Second, power imbalances impose constraints on collaborative processes [69, 70]. Actors who are less powerful in terms of resources, information, voice, or legitimacy may be excluded from participation [71] or may be embezzled by more dominant participants. Despite the importance of such concerns, there is little theory to guide stakeholders and researchers in understanding how power shapes hybrid governance processes and outcomes.

Few existing models of power are well suited for explaining and illustrating the role of power in the 


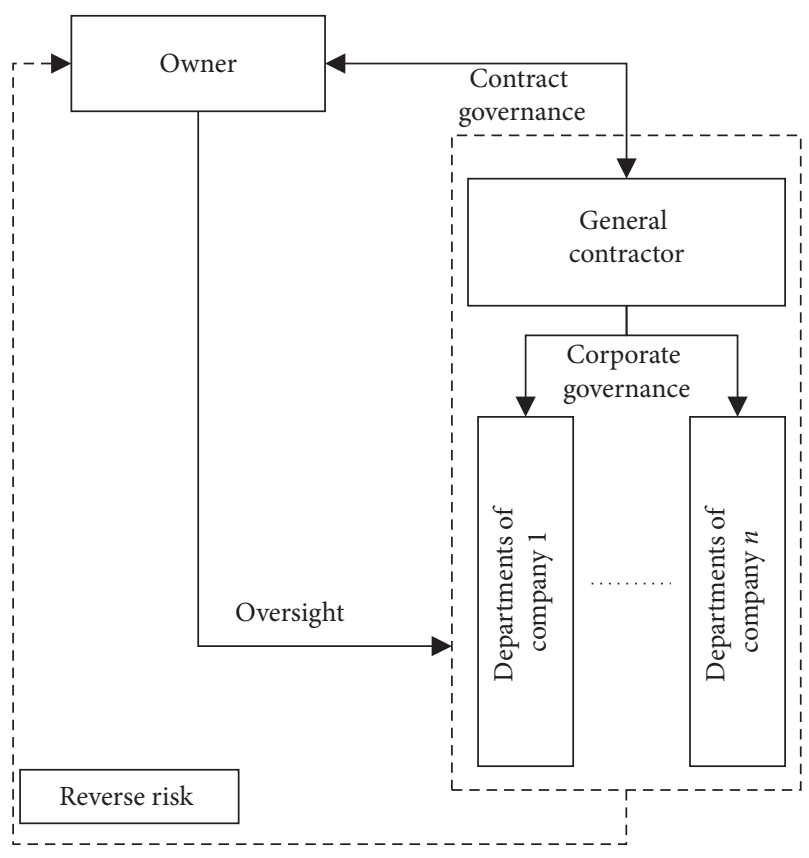

Figure 1: Hybrid governance structure in a megaproject.

governance structure of intra-organization and inter-organization. This is the reason why governance processes are ambiguous, complex contexts where information asymmetry, many participants, multidimensional management and governance structures, and processes can change rapidly based on risk. This highlights the need to discuss and consider the sources of power held by hybrid governance participants and the factors that influence governance processes with respect to the use of power. This research is conducted in combination with trust in the next section. Therefore, this paper proposed the following hypotheses $\left(\mathrm{H}_{1 \mathrm{a}}\right.$ and $\left.\mathrm{H}_{1 \mathrm{~b}}\right)$ related to power asymmetry, power sharing, and performance.

$\mathrm{H}_{1 \mathrm{a}}$ : power asymmetry is negatively related to hybrid governance performance. An increased level of power asymmetry is associated with poorer hybrid governance performance.

$\mathrm{H}_{1 \mathrm{~b}}$ : power sharing can advance improvements in hybrid governance performance. A higher amount of power sharing is associated with better hybrid governance performance.

2.2.2. Trust in Project Governance. Arrow [72] noted that virtually every commercial transaction involves an element of trust. Trust refers to an expectation, based on experience, that a partner will not behave opportunistically [73]. Trust is the main theme of control mechanisms in hybrid governance to reduce transaction costs, promote project success and performance, mitigate behavioral risks (especially opportunistic behavior), and reduce coordination costs [74]. This reduces the need for extensive formal contracts [75], among other mechanisms. Williams [76] noted that interpersonal trust is an important social resource that facilitates collaboration and enables coordinated social interaction. However, trust is not a control mechanism like power. Instead, it is a substitute for control by power [77] and can complement power mechanisms in hybrid governance.

Different types of trust are deeply embedded in megaprojects, which concern many interested entities (i.e., owner, contractor, designer, supervisor, and public). In this setting, interpersonal, intra-organization, and inter-organization trust become intertwined and interacted [78]. Psychology, management and workplace relations, behavioral law and economics, sociology, philosophy, and law are all needed to understand the interactions involved with trust and may provide more details needed to explain and illustrate the role of trust in megaproject. Because of the intertwined relationship between power and trust, this paper describes the kinds of power and trust held by participants in hybrid governance processes and reveals how the mutual influence and interaction between trust and power can impact project success and project performance. Therefore, this paper proposed the following hypothesis $\left(\mathrm{H}_{2}\right)$ relating trust and performance.

$\mathrm{H}_{2}$ : an effective trust level for realizing benefits improves hybrid governance performance. A higher trust level is associated with higher hybrid governance performance, and a lower trust level is associated with a lower hybrid governance performance.

2.2.3. Power and Trust in Hybrid Governance Approaches Affect Project Performance. The relationship between power and trust has been analyzed largely through the control function shared by power and trust [79]. This paper discusses power and trust in the context of hybrid governance at organizational (intra and inter) levels, rather than the single perspective of the owner or contractor. The research focuses on two dimensions (contract governance and corporate governance) of power and trust that have been discussed frequently in hybrid governance literature. This includes power asymmetry, power sharing, and trust levels in the inter/intra-organizational interactions of megaprojects.

In the megaproject environment, we expect power asymmetry or the sharing of control approaches to have a stronger impact on hybrid governance performance at low trust levels, while control is expected to have an inconspicuous impact in high trust level scenarios. Hence, this paper proposed the following moderating hypotheses $\left(\mathrm{H}_{3 a}\right.$ and $\mathrm{H}_{3 \mathrm{~b}}$ ) (also illustrated graphically in Figure 2).

$\mathrm{H}_{3 \mathrm{a}}$ : power asymmetry negatively influences trust and affects megaproject performance. Power moderates the relationship between trust level and hybrid governance performance. (1) The more negative the influence of coercive power on the trust level is, the more the power asymmetry impacts hybrid governance performance. (2) The more negative the influence of noncoercive power on the trust level is, the less the power asymmetry there is on hybrid governance performance. 


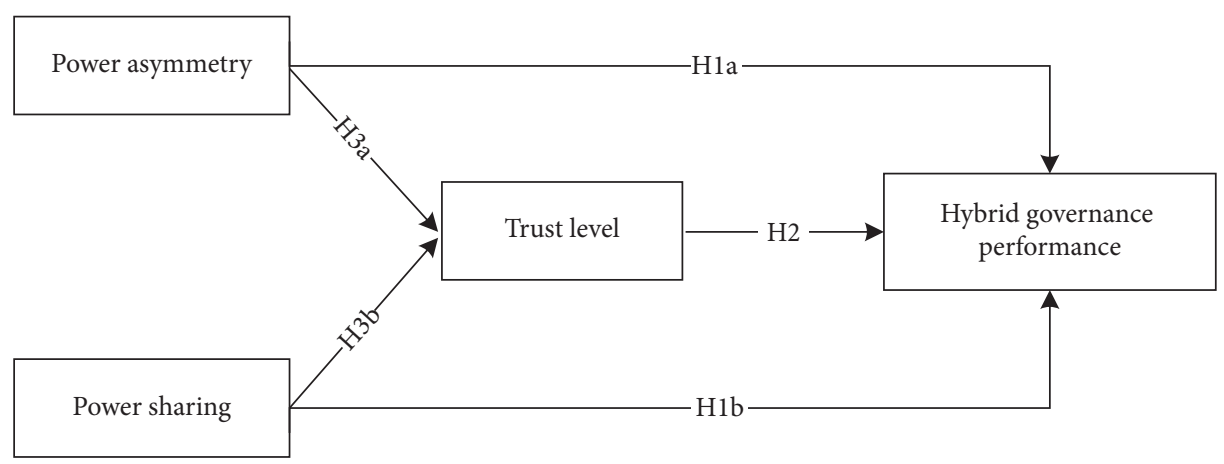

Figure 2: The study's theoretical model of power and trust in hybrid governance.

$\mathrm{H}_{3 \mathrm{~b}}$ : power sharing positively influences trust and affects megaproject performance. (1) The more positive the influence of noncoercive power on trust is, the more the impact there is on hybrid governance performance.

(2) The more positive the influence of coercive power on trust is, the less the impact there is on hybrid governance performance.

By applying a power-trust-performance perspective, this study explored major functions shared by power and trust level in the hybrid governance of megaprojects. Next, we argue that the combination of power and trust can contribute to the formation of collective goals, group consensus, and shared values, which can lead to improvements for the owner, general contractor and their departments, and other partners. By complementing critical factors in hybrid governance, these methods play a significant role in advancing megaproject performance, by reducing risks caused by moral hazard and opportunistic behaviors.

\section{Research Method}

The following methodologies were developed to achieve the research objective and test the study hypotheses. First, metrics were developed to measure power and trust among megaproject partners (owner, general contractor, and departments in general contractor). Then, metrics were developed to measure megaproject hybrid governance performance success. A questionnaire survey was subsequently developed and administered to measure power and trust among megaproject partners and the associated hybrid governance performance success.

3.1. Participants and Procedure. This study targeted urban rail transit projects, which are recognized as a type of transport megaproject with significant social, economic, and environmental impacts [80]. This required establishing a theoretical framework to evaluate the specific path of powertrust-performance throughout the full life cycle of the metro construction process. This provides stakeholders (owner, general contractor, and their departments) a sound basis for assessing existing trust levels.
3.1.1. Questionnaire Design. As discussed above, many power, trust, and project governance factors affect the performance of a megaproject. Several exploratory interviews were conducted with specialists to gather their opinions about the power and trust levels in the intra/intermetro construction organization. The exploratory interviews and literature analysis resulted in the identification of 26 influencing factors, which were included in the study questionnaire. Table 1 lists the 4 power asymmetry factors and 4 power sharing factors in the power dimension, 5 interorganizational (owner and general contractor) factors, and 5 intra-organizational (general contractor and their departments) factors in the trust level dimension. There were 8 hybrid governance performance factors that could affect project performance in project management and governance for metro construction. Each influencing factor is explained in detail in Table 1.

For each metro construction project, questionnaires were distributed to targeted owners and project managers, who were asked to report on trust, power, and risk for the most recent project they had managed. They were also asked to provide contact details of their supervisors. Owners and project managers' supervisors for the same projects were also asked to assess the level of urban rail transport project performance. A call for study participation was sent by e-mail to members of five metros in Tianjin, Guangzhou, Beijing, Shenzhen, and Shanghai, which belong to China's Association of Metros. This group was selected because of their familiarity and experience with the urban rail transport project environment.

3.1.2. Questionnaire Response. The questionnaire was distributed in five different cities of China (Tianjin, Guangzhou, Beijing, Shenzhen, and Shanghai) with ongoing metro construction projects. Responses to the questionnaire were voluntary and anonymous. In total, 200 questionnaires were distributed and 116 were returned. Out of the 116 complete owner-project manager-supervisor dyads received, 36 responses were received from Guangzhou Metro, 21 from Tianjin rail transit, 33 from Beijing Subway, 14 from Shanghai metro, and the remainder from Shenzhen metro. A total of $25.6 \%$ of responses came from general contractors, 


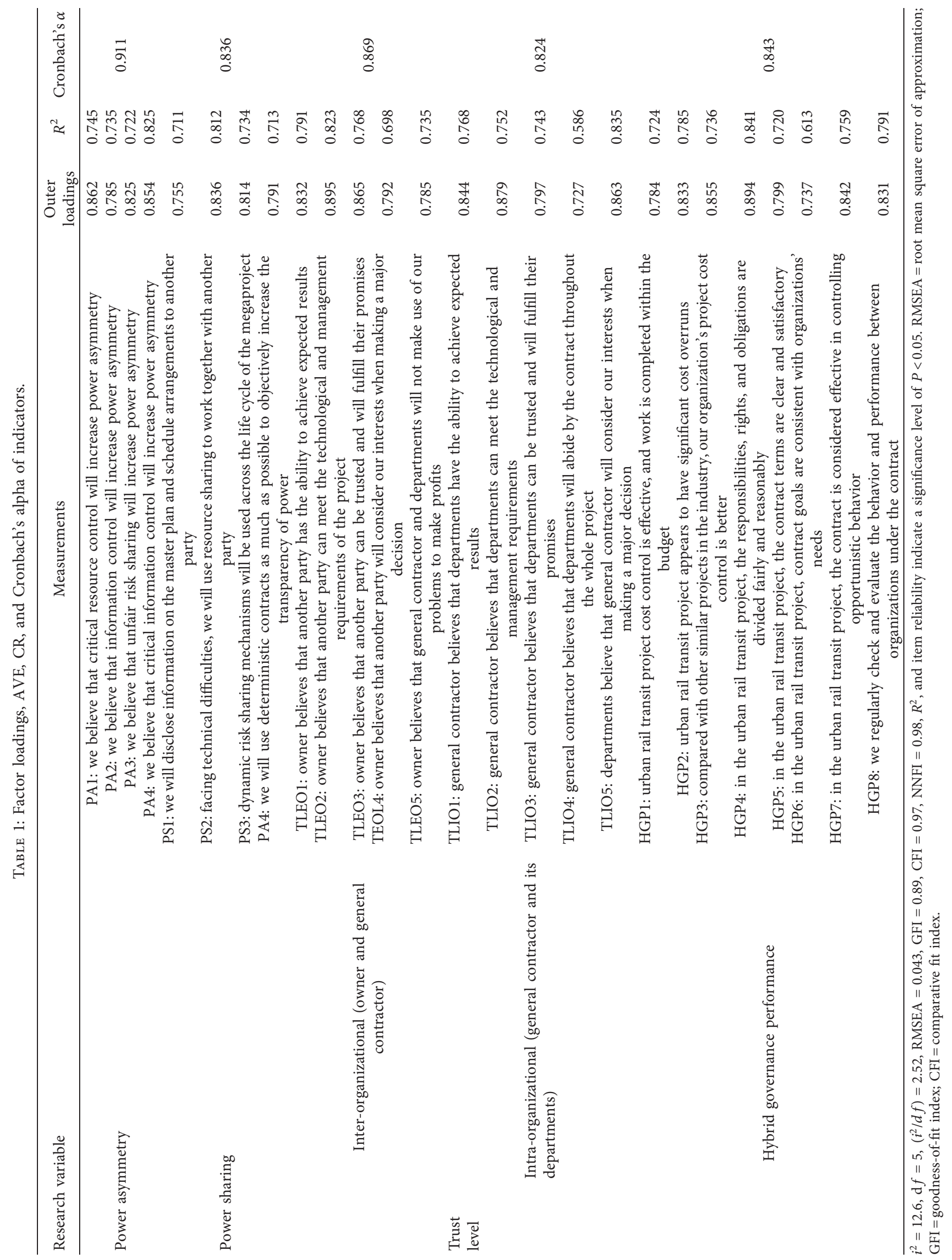


$26 \%$ from owners, $33.5 \%$ from departments within the general contractor organization, and $14.9 \%$ from government representatives. Urban rail transit project durations ranged between 48 and 90 months, with a mean of 68.5 months. A total of $75.4 \%$ of projects were undertaken by the government, while $24.6 \%$ of projects were commissioned through a public-private partnership. In terms of gender, $63.7 \%$ of respondents identified as male and $36.3 \%$ identified as female.

\subsection{Measures}

3.2.1. Governance Performance. Schedule, cost, and quality control are main objectives in construction project management [81] and are also specific indicators of project performance. The triple constraint, or the iron triangle of schedule-cost-quality, was used to measure the performance of hybrid governance and management. It was also used to determine the general levels of satisfaction that the owner, general contractor, and general contractor departments had with the benefits achieved at the project's completion. Simultaneously considering project duration, cost, and quality and maintaining a balance between them during the full process of hybrid governance are significant in improving overall benefits and performance of a megaproject, such as an urban rail transit project. The items were measured on a five-point Likert scale ( $1=$ low to $5=$ high $)$. The scale's alpha coefficient was 0.82 .

3.2.2. Power Asymmetry. Power asymmetry is commonly noted as a problem because power is consistently distributed asymmetrically across participants. This may lead to manipulation if stronger actors collaborate [82-84]. Study findings have indicated that while power asymmetries do affect governance modes, the process by which the power asymmetry affects governance mechanism is less well understood [85]. This paper proposes that the power asymmetry is related to hybrid governance mechanism through the perceived trust level. These variables were assessed using a five-point Likert scale $(1=$ low to $5=$ high $)$. The scale's alpha coefficient was 0.83 .

3.2.3. Power Sharing. Power sharing can produce an ethos of collaboration and trust [86]; promote sharing of responsibility, knowledge, and risk [86]; establish firm partnerships [87]; secure legitimacy of governance [88]; and reduce fragmentation [89]. There are also difficulties associated with power sharing, including the time-consuming process of fostering the trust needed to share power; the potential for stalemates and inaction caused by the poor implementation of power; or a failure in collaboration due to an unwillingness to share power. These variables were gauged using a five-point Likert scale ( $1=$ low to $5=$ high). The scale's alpha coefficient was 0.84 .

3.2.4. Trust Level. Trust can be created, attained, and supplemented using different trust building measures [90].
Hybrid organizations in urban rail transit projects have a continuously changing and evolving landscape. Therefore, adopting trust and power to improve the project's conditions can maximize gains across partners. Trust has been found to be a predictor of project performance [91], and power asymmetry has a significant positive moderating effect on the impact of allied experience on innovative performance (Chao 2011). These variables were gauged using a five-point Likert scale $(1=$ low to $5=$ high $)$. The scale's alpha coefficient was 0.82 .

3.3. Data Analysis. Structural equation modelling (SEM) is a multivariate technique used to explore and test the relationship between variables. SEM contains both observable variables and potential variables that cannot be directly observed. Hair et al. [92] noted that SEM encompasses regression analysis, factor analysis, multiple correlations, and path analysis. This makes it a robust tool that can clearly analyze the effect of individual indicators on the population and the relationship between individual indicators. This method is applied to simultaneously analyze multiple variables. The measurements collected from self-administered questionnaire surveys are generally used to collect primary data [93]. SEM has been widely used in previous construction management studies [94-97].

In this study, the elements or items were coded according to the factor or latent construct; the data were then analyzed using SPSS and AMOS software. The factor codes were as follows: power asymmetry was "PA," power sharing was "PS," the inter-organizational trust level was "TLEO," the intra-organizational trust level was "TLIO," and hybrid governance performance was "HGP." In the first stage of data analyses, the exploratory factor analysis (EFA), data were purified using the AVE, CR, and Cronbach's alpha of indicators, as shown in Table 2. The remaining items were analyzed using within-block EFA, factor loading of the entire set, and Cronbach's $\alpha$ techniques. This allowed for assessments of dimensionality and reliability. As a result, the EFA confirmed that the constructs were significant and had a good reliability for confirmatory factor analysis (CFA). Generally, the accepted cutoff for item loadings is 0.70 or greater [98]. Table 2 shows that $0.824<\alpha<0.911$, indicating that all factor loadings were equal to or greater than the recommended cutoff value. Therefore, individual item reliability was considered to be significantly robust.

Table 1 lists the overall fit indicators for the confirmatory factor analysis. When $\left(i^{2} / d f\right)<2$, the SEM for power-trustperformance fit well, with a higher prediction accuracy. When $2.0<\left(i^{2} / d f\right)<5.0$, the model is acceptable. Based on Table $1,\left(i^{2} / d f\right)<2.62 \in(2,5)$. As such, the result is accepted, based on the goodness-of-fit index (GFI) and comparative fix index (CFI) at a cutoff of 0.9 and the root mean square error of approximation (RMSEA). In conclusion, the overall goodness of fit for the proposed measurement model provided sufficient support for us to consider the results representative of the hypothesized construct. Furthermore, assessments of validity were also conducted. They concluded that the convergent validity 
TABle 2: Pearson correlations among the study's continuous variables.

\begin{tabular}{lccccc}
\hline & Mean & PA & PS & TL & HGP \\
\hline PA & 3.51 & 1 & & & \\
PS & 3.42 & 0.762 & 1 & & \\
TL & 3.21 & 0.756 & 0.698 & 1 & \\
HGP & 3.64 & 0.823 & 0.768 & 0.724 & 1 \\
\hline
\end{tabular}

$\mathrm{PA}=$ power asymmetry; $\mathrm{PS}=$ power sharing; $\mathrm{TL}=$ trust level; $\mathrm{HGP}=$ hybrid governance performance.

results were marginally acceptable, as all items have a factor of loading larger than 1.96 and exhibited an $R^{2}$ value exceeding 0.413 . Results showed significant positive correlations between the two management approaches that might be adopted by the megaproject owner, general contractor, and their departments in discharging his/her power asymmetry/sharing and trust level and hybrid governance performance.

\section{Results}

4.1. The Moderating Effect of Trust Level. The second set of research hypotheses (H2) focused on the moderating effect of inter-organizational and intra-organizational trust level on hybrid governance performance. Conditions set by [99] were tested first to facilitate a moderation test. The correlation analysis (see Table 2) found no significant correlations between the moderating variable (trust level), the predictors (power asymmetry/sharing and trust level), and the criterion variable (hybrid governance performance).

As a result, this case fell within the second quadrant in Sharma et al.'s model as a full moderator. In other words, the moderating variable was related to neither the criterion nor the predictor, nor did it interact with the predictor. Hence, a moderation analysis was conducted using a stepwise regression, as described above.

4.2. Results of the Structural Equation Modelling. The convergent validity was assessed by examining the loading and its statistical significance through the $t$-value, also known as a critical ratio (C.R.) in AMOS. A C.R. value greater than 1.96 or smaller than -1.96 indicated statistical significance [100].

With respect to R2 item reliability, Table 3 shows the results of the hypotheses constructed using the research framework, along with the C.R. value. A value that was larger than 1.96 or smaller than -1.96 represented a significance level of 0.05 . This result supported the null hypothesis. In contrast, a value falling between 1.96 and -1.96 indicated that the null hypothesis was rejected.

\section{Discussion}

This section discusses the effectiveness of power and trust on hybrid governance performance in urban rail transit project contexts. Power asymmetry and power sharing can be somewhat assessed using the trust level among owner, general contractor, and the departments of the general contractor. In addition to confirming the positive relationship between the power asymmetry/sharing of megaproject stakeholders with respect to hybrid governance performance, the results of this study also exposed the mediating effect of the trust level. This reinforced the importance of the trust level as a contextual construct in megaproject hybrid governance. More specifically, this study found that under low and high levels of trust in inter-organization or intra-organization in the alliance of a megaproject, each management or governance approach to the discharge of power asymmetry/sharing has a different impact on contract governance and corporate governance with respect to hybrid governance performance.

The study found that megaproject stakeholders' power asymmetry and power sharing of the hybrid governance process is important with respect to different trust levels in different situations. Furthermore, the owner, the general contractor, and the departments of the general contractor form a complex hybrid alliance that includes two kinds of governance relationships: the contract governance between the owner and the general contractor, known as the interorganizational relationship; and the corporate governance, created because the general contractor is a large firm with many departments. Therefore, situations involving high or low trust levels due to different levels of power asymmetry and power sharing can affect hybrid governance performance.

This study investigated the connection between power and trust level and megaproject hybrid governance performance and explored the multiple mediating effects of cooperative behavior in urban rail transit projects. The empirical findings show that, as a core element of contract governance and corporate governance in hybrid governance, power and trust played a key role in conserving megaproject performance. Power and trust in the intra-organizational and inter-organizational constructs of a megaproject significantly impacted project performance. The owner, general contractor, and departments within the general contractor took on different responsibilities in hybrid governance. Furthermore, power asymmetry and power sharing were the two important project tactics in hybrid governance, with multiple mediating effects impacting the trust level within and outside megaproject organization. This study contributes to the literature on the nexus of inter-organizational trust levels, inter-organizational trust levels, and multiple mediating effects in improving hybrid performance.

The first contribution of this empirical study relates to the ways in which power asymmetry and power sharing impact inter-organizational trust level and hybrid performance. Although some studies have analyzed organizational performance from the perspective of inter-organizational trust, most studies have treated trust as an independent construct [101]. A more intensive analysis of corporate governance in hybrid performance is needed to address internal cost control and risk allocation and benefit distribution between the general contractor and the departments of general contractor. The power structure of a megaproject determines its contract governance. When a megaproject uses a centralized pattern held by the owner and power is out 
TABLE 3: Results of the structural equation modelling.

\begin{tabular}{|c|c|c|c|c|c|}
\hline Hypotheses & Variables & Estimate & Standard error (S.E.) & Critical ratio (C.R.) & Result \\
\hline $\mathrm{H}_{1 \mathrm{a}}$ & Power asymmetry $\longrightarrow$ performance & 0.561 & 0.13 & 2.132 & Accepted \\
\hline $\mathrm{H}_{1 \mathrm{~b}}$ & Power sharing $\longrightarrow$ performance & 0.452 & 0.15 & 2.546 & Accepted \\
\hline $\mathrm{H}_{3 \mathrm{a}}$ & Power asymmetry $\longrightarrow$ trust level & 0.378 & 0.14 & 2.341 & Accepted \\
\hline $\mathrm{H}_{3 b}$ & Power sharing $\longrightarrow$ trust level & 0.685 & 0.213 & 3.624 & Accepted \\
\hline $\mathrm{H}_{2}$ & Trust level $\longrightarrow$ performance & 0.653 & 0.161 & 3.256 & Accepted \\
\hline
\end{tabular}

S.E: standard error and C.R: critical ratio ( $t$ value)

of balance, the general contractor needs to seek power to improve megaproject performance. Responsibility, procedure, and scope focused on contract governance across the life cycle of megaproject. Moreover, power asymmetry, power sharing, and trust level building (joint action) have become integral parts of contract governance theory. As such, this study extends the existing theoretical boundaries and helps systematically analyze and determine their impact on megaproject contract performance, as well as the theoretical relationship with owner and general contractor.

The second contribution of this study refers to the multiple mediating effects of joint action (power-trustperformance) between intra-organizational trust levels. This can advance the corporate governance performance of the general contractor. This is perhaps the most striking finding, as the study found that the general contractor's intra-organizational trust levels depended on the concentration of power, which was embodied in the power asymmetry and power sharing associated with the general contractor's rules and regulations and operating mechanisms. This study found that power asymmetry and power sharing played moderating roles, by upholding the balance of power among stakeholders. This further deconstructed the effect of intraorganizational trust level on megaproject performance from the perspective of corporate governance. More power sharing and less power asymmetry were associated with a higher trust level in the megaproject and greater ease in improving megaproject governance performance. In contrast, less power sharing and more power asymmetry were associated with a lower trust level between general contractor and its departments. This increased the project's internal transaction costs. As such, power and trust level had multiple mediating effects and shaped relationships between intra-organizational corporate governance performances.

Finally, the third contribution of this study lies in the moderating role of hybrid governance, composed of contract governance and corporate governance. Recent studies have focused on intra-organization and inter-organization relationships between contractual and corporate governance in different megaproject governance situations, [102-104] and it also impacts on time, quality, cost, value systems, responsibilities, processes, and policies, or dynamic effects [102-104]. This study found that hybrid governance had different moderating effects on the impact of trust and power on contract governance and corporate governance strategies with respect to megaproject hybrid governance performance. The results revealed that a power asymmetry in contract governance or corporate governance may negatively affect the trust level on hybrid governance performance, when the intensity of contract governance or corporate governance was low. However, power sharing played a positive role in this situation. To this end, contract governance should emphasize cooperation by strengthening coordination clauses, reducing control-focused clauses, and increasing flexibility in contract execution. In addition, corporate governance should formulate rules and procedures to regulate the power of the general contractor and its departments. Megaproject stakeholders enhanced trust level by using power only to advance megaproject performance through hybrid governance.

\section{Conclusion}

Research on the influence of power asymmetry, power sharing, and intra-organizational and inter-organizational trust levels on project costs, using the perspective of hybrid governance, remains in its infancy. There is much to learn by examining different variables. Power and trust differ from governance forms of organization or project teams; these elements impact intra-organizational and inter-organizational relationships, bring new challenges for stakeholders, and significantly impact megaproject governance performance. This study empirically gathered evidence about power-trust-performance effects, indicating that power asymmetry and power sharing are important process strategies for developing trust in hybrid governance and can play mediating roles in developing intra-organizational and inter-organizational trust. Moreover, megaproject hybrid governance is the bedrock of a working relationship between key stakeholders, including the owner, general contractor, and their departments. Hybrid governance moderates the effect of contract or corporate governance on megaproject performance. Megaproject stakeholders can therefore learn to better leverage power asymmetry and power sharing to impact trust levels in megaproject organizations and can use hybrid governance to improve megaproject performance.

Although the empirical data for this study were from urban rail transit projects in six cities of China, those metro projects share general characteristics, including bounded rationality, moral hazard, opportunism, cost overruns, mixed organization, and complicated working relationships. Moreover, the SEM model tested hypotheses of power, trust, and project performance, which were based on general theories of contract and corporate governance and based on the literature. Consequently, the research findings are generalizable, allowing other urban rail transit projects or other megaprojects to refer to them [105]. 


\section{Data Availability}

The data used to support the findings of this study are included within the article.

\section{Conflicts of Interest}

The authors declare that they have no conflicts of interest.

\section{References}

[1] B. V. Wee, "Large infrastructure projects: a review of the quality of demand forecasts and cost estimations," Environment \& Planning B Planning \& Design, vol. 34, no. 4, pp. 611-625, 2008.

[2] W. M. Edward, "Industrial megaprojects: concepts, strategies, and practices for success," Chemical Engineering World, Wiley, Hoboken, NJ, USA, 2016.

[3] N. Brookes, D. Sage, A. Dainty, G. Locatelli, and J. Whyte, "An island of constancy in a sea of change: rethinking project temporalities with long-term megaprojects," International Journal of Project Management, vol. 35, no. 7, pp. 1213-1224, 2017.

[4] B. Flyvbjerg, The Oxford Handbook of Megaproject Management, Oxford University Press, New York, NY, USA, 2017.

[5] B. Flyvbjerg, "What you should know about megaprojects and why: an overview," Project Management Journal, vol. 45, no. 2, pp. 6-19, 2014.

[6] H. Lin, S. Zeng, H. Ma, R. Zeng, and V. W. Y. Tam, “An indicator system for evaluating megaproject social responsibility," International Journal of Project Management, vol. 35, no. 7, pp. 1415-1426, 2017.

[7] D. Wang, H. Fu, and S. Fang, "The efficacy of trust for the governance of uncertainty and opportunism in megaprojects," Engineering, Construction and Architectural Management, vol. 27, no. 1, pp. 150-167, 2019.

[8] B. Flyvbjerg and A. Stewart, Olympic Proportions: Cost and Cost Overrun at the Olympics 1960-2012, Social Science Electronic Publishing, Rochester, NY, USA, 2012.

[9] C. I. Ikea, "Comprehensive objectives for PPP projects: case of Beijing olympic stadium," International Journal of Business \& Management, vol. 8, no. 9, 2013.

[10] M. S. Ramabodu and J. J. P. Verster, "Factors that influence cost overruns in South African public sector mega-projects," International Journal of Project Organisation and Management, vol. 5, no. 1-2, pp. 48-56, 2013.

[11] J. Mattias and L. W. Timothy, "Tinkerbell and the empire state building: recalling what seems to be forgotten," $P M$ World Journal, vol. 5, no. 5, pp. 1-4, 2018.

[12] N. J. Brookes and G. Locatelli, "Power plants as megaprojects: using empirics to shape policy, planning, and construction management," Utilities Policy, vol. 36, no. OCT, pp. 57-66, 2015.

[13] E. Z. Al-Sibaie, A. M. Alashwal, H. Abdul-Rahman, and U. K. Zolkafli, "Determining the relationship between conflict factors and performance of international construction projects," Engineering, Construction and Architectural Management, vol. 21, no. 4, pp. 369-382, 2014.

[14] G. Wu, X. Zhao, J. Zuo et al., "Effects of contractual flexibility on conflict and project success in megaprojects," International Journal of Conflict Management, vol. 29, no. 2, pp. 253-278, 2017.
[15] Y. J.-T. Zidane, B. A. Hussein, J. Ø. Gudmundsson, and A. Ekambaram, "Categorization of organizational factors and their impact on project performance," Procedia-Social and Behavioral Sciences, vol. 226, pp. 162-169, 2016.

[16] P. O. Akanni, A. E. Oke, and O. A. Akpomiemie, "Impact of environmental factors on building project performance in Delta State, Nigeria," HBRC Journal, vol. 11, 2015.

[17] P. M. Panayides, F. Parola, and J. S. L. Lam, "The effect of institutional factors on public-private partnership success in ports," Transportation Research Part A: Policy and Practice, vol. 71, no. jan, pp. 110-127, 2015.

[18] K. Kim, "Project performance evaluation of multi-prime contracts in comparison with general contractor contracts," Journal of Asian Architecture and Building Engineering, vol. 16, no. 3, pp. 613-618, 2017.

[19] L. M. Amusan, A. Afolabi, R. Ojelabi, I. Omuh, and H. I. Okagbue, "Data exploration on factors that influences construction cost and time performance on construction project sites," Data in Brief, vol. 17, pp. 1320-1325, 2018.

[20] T. R. Browning, "Planning, tracking, and reducing a complex project's value at risk," Project Management Journal, vol. 50, no. 1, pp. 71-85, 2019.

[21] O. O. Oshinubi, “The influence of project managers' leadership styles on project team performance in the construction industry," Dissertations \& Theses, Georgia Institute of Technology, Atlanta, GA, USA, 2007.

[22] Y. L. Yin, Z. C. Xu, and Q. S. Zou, "Research on bias of owner's decision-making in risk-sharing in construction project-a perspective of bounded rationality," Applied Mechanics and Materials, vol. 357-360, pp. 2164-2170, 2013.

[23] R. Ndihokubwayo and T. Haupt, Factors Influencing the Occurrence Of Variation Orders And Their Impact On Project Performance, South African Council for Quantity Surveying Profession Conference, Midrand, South Africa, 2008.

[24] M. Amir, T. Mehdi, and K. Yahya, "Factors influencing safety performance on construction projects: a review," Safety Science, vol. 109, pp. 382-397, 2018.

[25] O. E. Williamson, The Economic Institutions of CapitalismTransaction Cost Economics, The Free Press-Macmillan, New York, NY, USA, 1985.

[26] O. E. Williamson, "Comparative economic organization: the analysis of discrete structural alternatives," Administrative Ence Quarterly, vol. 36, 1991.

[27] D. Binchao, Y. Yilin, W. Yihong et al., "Deconstructing hybrid governance for general contracting of large public project," Journal of Engineering Management, vol. 33, no. 6, pp. 30-35, 2019.

[28] O. E. Williamson and W. Ouchi, "Markets and hierarchies, analysis and antitrust implications: a study in the economics of internal organization," Administrative Science Quarterly, vol. 22, pp. 382-384, 1977.

[29] N. G. Noorderhaven, "Transaction, interaction, institutionalization: toward a dynamic theory of hybrid governance," Scandinavian Journal of Management, vol. 11, no. 1, pp. 43-55, 2011.

[30] A. Mert, "Hybrid governance mechanisms as political instruments: the case of sustainability partnerships," International Environmental Agreements: Politics, Law and Economics, vol. 14, no. 3, pp. 225-244, 2014.

[31] A. Rezvani, P. Khosravi, and N. M. Ashkanasy, "Examining the interdependencies among emotional intelligence, trust, and performance in infrastructure projects: a multilevel study," International Journal of Project Management, vol. 36, no. 8, pp. 1034-1046, 2018. 
[32] F. Sanne, J. Jennifer, W. Frank, and I. S. Janka, “Antecedents of leaders' power sharing: the roles of power instability and distrust," Organizational Behavior and Human Decision Processes, vol. 157, pp. 115-128, 2020.

[33] R. Müller, "ebrary Inc. Project governance," Strategic Direction, vol. 27, no. 2, 2011.

[34] E. G. Too and P. Weaver, "The management of project management: a conceptual framework for project governance," International Journal of Project Management, vol. 32, no. 8, pp. 1382-1394, 2014.

[35] C. Biesenthal and R. Wilden, "Multi-level project governance: trends and opportunities," International Journal of Project Management, vol. 32, no. 8, pp. 1291-1308, 2014.

[36] I. Filatotchev and C. Nakajima, "Internal and external corporate governance: an interface between an organization and its environment," British Journal of Management, vol. 21, no. 3, pp. 591-606, 2010.

[37] J. Kalodimos, "Internal governance and performance: evidence from when external discipline is weak," Journal of Corporate Finance, vol. 43, pp. 193-216, 2017.

[38] R. Derakhshan, R. Turner, M. Mancini et al., "Project governance and stakeholders: a literature review," International Journal of Project Management, vol. 37, no. 1, pp. 98-116, 2019.

[39] J. Kopmann, A. Kock, C. P. Killen, and H. G. Gemünden, "The role of project portfolio management in fostering both deliberate and emergent strategy," International Journal of Project Management, vol. 35, no. 4, pp. 557-570, 2017.

[40] A. u. Musawir, S. B. Abd-Karim, and M. S. Mohd-Danuri, "Project governance and its role in enabling organizational strategy implementation: a systematic literature review," International Journal of Project Management, vol. 38, no. 1, pp. 1-16, 2020.

[41] O. E. Williamson, Markets and Hierarchies, Analysis and Antitrust Implications: A Study in the Economics of Internal Organization, Free Press, New York, NY, USA, 1975.

[42] J. Liu, X. Zhao, and Y. Li, "Exploring the factors inducing contractors' unethical behavior: case of China," Journal of Professional Issues in Engineering Education \& Practice, vol. 143, no. 3, pp. 04016023.1-04016023.10, 2017.

[43] M. Ikuabe, A. E. Oke, and C. Aigbavboa, "Impact of contractors' opportunism on construction project transaction costs: construction professionals' perception," Journal of Financial Management of Property and Construction, vol. 25, 2020.

[44] E. E. Per and L. Hans, "Strategies for reducing moral hazard in construction procuremengt: a conceptual framework," Journal of Self-Governance and Management Economic, vol. 4, no. 1, pp. 7-33, 2016.

[45] A. Thomasson, "Navigating in the landscape of ambiguity: a stakeholder approach to the governance and management of hybrid organisations," Lund Studies in Economics \& Management, 2009.

[46] V. Blazevic, C. Reypens, and A. Lievens, "Hybrid Orchestration in Multi-stakeholder Innovation Networks: practices of mobilizing multiple, diverse stakeholders across organizational boundaries," Organization Studies, vol. 42, 2021.

[47] E. Sternberg, "Preparing for the hybrid economy: the new world of public-private partnerships," Business Horizons, vol. 36, no. 6, pp. 11-15, 1993.

[48] D. K. Panda, Organizational Collaboration, Hybrid Structure, Governance and Value Creation Evidence from Indian PublicPrivate Partnerships, ResearchGate, Berlin, Germany, 2015.

[49] H. Evanschitzky and B. Caemmerer, "The franchise dilemma: agent motivations, contracting, and opportunism in hybrid governance," The Sustainable Global Marketplace, Springer, Berlin, Germany, 2015.

[50] M. Powell, A. Gillett, and B. Doherty, "Sustainability in social enterprise: hybrid organizing in public services," Public Management Review, vol. 21, no. 1-2, pp. 159-186, 2018.

[51] A. Verma and J. P. Terpenny, "Dynamic project management: a principal-agent based approach," International Journal of Physical Distribution \& Logistics Management, vol. 36, no. 7, pp. 490-506, 2005.

[52] C.-Y. Chang, "Principal-agent model of risk allocation in construction contracts and its critique," Journal of Construction Engineering \& Management, vol. 140, no. 1, Article ID 04013032, 2014.

[53] D. Páez-Pérez and M. Sánchez-Silva, "A dynamic principalagent framework for modeling the performance of infrastructure," European Journal of Operational Research, vol. 254, no. 2, pp. 576-594, 2016.

[54] S. Ping Ho, R. Levitt, C. W. Tsui et al., "Opportunism-focused transaction cost analysis of public-private partnerships," Journal of Management in Engineering, vol. 31, no. 6, Article ID 04015007, 2015.

[55] S. V. Devarakonda, Reuer, and J. Jeffrey, "Mechanisms of hybrid governance: administrative committees in non-equity alliances," Academy of Management Journal, vol. 59, 2016.

[56] B.-G. Hwang, X. Zhao, and G. S. Yu, "Risk identification and allocation in underground rail construction joint ventures: contractors' perspective," Journal of Civil Engineering and Management, vol. 22, no. 6, pp. 758-767, 2015.

[57] X. Zhao, B.-G. Hwang, and S. P. Low, "An enterprise risk management knowledge-based decision support system for construction firms," Engineering, Construction and Architectural Management, vol. 23, no. 3, pp. 369-384, 2016.

[58] P. A. Martinus and S. O. Ogunlana, "Good project governance for proper risk allocation in public-private partnerships in Indonesia," International Journal of Project Management, vol. 24, pp. 622-634, 2006.

[59] Y. Tang, Y. Chen, Y. Hua, and Y. Fu, "Impacts of risk allocation on conflict negotiation costs in construction projects: does managerial control matter?" International Journal of Project Management, vol. 38, no. 3, pp. 188-199, 2020.

[60] B. Reinhard, "Trust, power and control in trans-organizational relations," Organization Studies, vol. 22, pp. 336-365, 2001.

[61] J. M. Purdy, "A framework for assessing power in collaborative governance processes," Public Administration Review, vol. 72, no. 3, pp. 409-417, 2012.

[62] B. Ran and H. Qi, "The entangled twins: power and trust in collaborative governance," Administration \& Society, vol. 51, no. 4, pp. 607-636, 2019.

[63] R. M. Emerson, "Power-dependence relations," American Sociological Review, vol. 27, no. 1, pp. 31-41, 1962.

[64] S. D. Hunt and J. R. Nevin, "Power in a channel of distribution: sources and consequences," Journal of Marketing Research, vol. 11, no. 2, pp. 186-193, 1974.

[65] S. Dawson, Analyzing Organizations, Macmillan Business, London, UK, 1996.

[66] A. Soleimani, W. D. Schneper, and W. Newburry, "The impact of stakeholder power on corporate reputation: a cross-country corporate governance perspective," Organization Science, vol. 25, no. 4, pp. 991-1008, 2014.

[67] B. J. Broome, "Participatory planning and design in a protracted conflict situation: applications with citizen peacebuilding groups in Cyprus," Systems Research and Behavioral Science, vol. 19, no. 4, pp. 313-321, 2002. 
[68] X. X. Huang and Z. S. Yang, "Project executive ability research under lean construction," Applied Mechanics and Materials, vol. 174-177, pp. 2806-2810, 2012.

[69] C. Taehyon and P. J. Robertson, "Deliberation and decision in collaborative governance: a simulation of approaches to mitigate power imbalance," Journal of Public Administration Research \& Theory, vol. 24, no. 2, pp. 495-518, 2014.

[70] R. L. Wise, "A crisis of investor confidence: corporate governance and the imbalance of power," Advances in Financial Economics, vol. 16, pp. 217-261, 2013.

[71] D. B. Spence, "Agency discretion and the dynamics of procedural reform," Public Administration Review, vol. 59, no. 5, pp. 425-442, 1999.

[72] K. J. Arrow, "Gifts and exchanges," Philosophy \& Public Affairs, vol. 1, no. 4, pp. 343-362, 1972.

[73] C. Tomkins, "Interdependencies, trust and information in relationships, alliances and networks," Accounting, Organizations and Society, vol. 26, no. 2, pp. 161-191, 2001.

[74] R. Gulati and H. Singh, "The architecture of cooperation: managing coordination costs and appropriation concerns in strategic alliances," Administrative Science Quarterly, vol. 43, no. 4, pp. 781-814, 1998.

[75] A. Larson, "Network dyads in entrepreneurial settings: a study of the governance of exchange relationships," Administrative Science Quarterly, vol. 37, no. 1, pp. 76-104, 1992.

[76] Q. E. Williamson, "The economics of internal organization: exit and voice in relation to markets and hierarchies," Journal of American Economic Review, vol. 66, no. 2, pp. 369-377, 2001.

[77] D. M. Rousseau, "The "problem" of the psychological contract considered," Journal of Organizational Behavior, vol. 19, no. S1, pp. 665-671, 1998.

[78] R. Gulati and J. A. Nickerson, "Interorganizational trust, governance choice, and exchange performance," Organization Science, vol. 19, no. 5, pp. 688-708, 2008.

[79] R. Bing and Q. Huiting, "Contingencies of power sharing in collaborative governance," The American Review of Public Administration, vol. 48, pp. 836-851, 2018.

[80] X. Zhao, Y. Ke, J. Zuo, W. Xiong, and P. Wu, "Evaluation of sustainable transport research in 2000-2019," Journal of Cleaner Production, vol. 256, p. 120404, 2020.

[81] M. Chadaga, K. N. Lohith, and Gurucharan, "Analysis of cost-duration-quality of on going project," Journal Civil Engineering, vol. 2012, no. 1, pp. 1-13, 2012.

[82] A. A. Gash, "Collaborative governance in theory and practice," Journal of Public Administration Research \& Theory J Part, vol. 18, no. 4, pp. 543-571, 2008.

[83] J. M. Bryson, B. C. Crosby, and M. M. Stone, "The design and implementation of cross-sector collaborations: propositions from the literature," Public Administration Review, vol. 66, no. s1, pp. 44-55, 2010.

[84] S. Vangen and C. Huxham, "Aiming for collaborative advantage: challenging the concept of shared vision," SSRN Electronic Journal, vol. 33, no. 4, pp. 8-9, 2005.

[85] E. Teimoury, M. Fesharaki, and A. Bazyar, "The relationship between mediated power asymmetry, relational risk perception, and governance mechanism in new product development relationships," Journal of Research in Interactive Marketing, vol. 4, no. 4, pp. 296-315, 2010.

[86] S. H. Linder, "Coming to terms with the public-private partnership," American Behavioral Scientist, vol. 43, no. 1, pp. 35-51, 1999.
[87] P. Carmichael and C. Knox, "Towards' a new era'? Some developments in governance of northern Ireland," International Review of Administrative Sciences, vol. 65, no. 1, pp. 103-116, 1999.

[88] S. Jentoft, T. C. van Son, and M. Bjørkan, "Marine protected areas: a governance system Analysis," Human Ecology, vol. 35, no. 5, pp. 611-622, 2007.

[89] C. N. Ehler, "Indicators to measure governance performance in integrated coastal management," Ocean \& Coastal Management, vol. 46, no. 3-4, pp. 335-345, 2003.

[90] S. U. Rehman, Q. Cao, G. Weiming et al., "Rise in level of trust and trustworthiness with trust building measures: a mathematical model," Journal of Modelling in Management, vol. 12, no. 3, pp. 349-363, 2017.

[91] I. Maurer, "How to build trust in inter-organizational projects: the impact of project staffing and project rewards on the formation of trust, knowledge acquisition and product innovation," International Journal of Project Management, vol. 28, no. 7, pp. 629-637, 2010.

[92] J. F. Hair, W. C. Black, B. J. Babin et al., Multivariate Data Analysis: A Global Perspective, Pearson Education, London, UK, 2010.

[93] J. F. Hair, G. T. Hult, C. M. Ringle, and M. Sarstedt, “A primer on partial least squares structural equation modelling (PLS-SEM)," Long Range Planning, vol. 46, no. 1-2, pp. 184-185, 2013.

[94] X. Zhao, P. Wu, and X. Wang, "Risk paths in BIM adoption: empirical study of China," Engineering, Construction and Architectural Management, vol. 25, no. 9, pp. 1170-1187, 2018.

[95] G. Wu, X. Zhao, J. Zuo, and G. Zillante, "Effects of team diversity on project performance in construction projects," Engineering, Construction and Architectural Management, vol. 26, no. 3, pp. 408-423, 2019.

[96] W. Jiang and X. Zhao, "Trust and the intent to cooperate in energy performance contracting for public buildings in China," Engineering, Construction and Architectural Management, vol. 28, no. 1, pp. 372-396, 2019.

[97] Y. Niu, X. Deng, X. Zhao, and N. Zhang, "Hexagonal diamond model for international competitive advantages of high-speed railway industry," Journal of Management in Engineering, vol. 36, no. 2, Article ID 04020001, 2020.

[98] M. E. Palanski, S. S. Kahai, and F. J. Yammarino, “Team virtues and performance: an examination of transparency, behavioral integrity, and trust," Journal of Business Ethics, vol. 99, no. 2, pp. 201-216, 2011.

[99] S. Sharma, R. Durand, and O. Gur-Arie, "Identification and analysis of moderator variables," Journal of Marketing Research, vol. 18, no. August, pp. 291-300, 1981.

[100] B. M. Byrne, "Structural equation modeling with AMOS, EQS, and LISREL: comparative approaches to testing for the factorial validity of a measuring instrument," International Journal of Testing, vol. 1, no. 1, pp. 55-86, 2001.

[101] S. O. Cheung, T. W. Yiu, and M. C. Lam, "Interweaving trust and communication with project performance," Journal of Construction Engineering and Management, vol. 139, no. 8, pp. 941-950, 2013.

[102] P. D. Galloway, K. Nielsen, and J. L. Dignum, "Governance of the megaproject," American Society of Civil Engineers, vol. 2012, no. 1, pp. 1-30, 2012.

[103] R. Müller, Project Governance, Routledge, New York, NY, USA, 2016.

[104] Y. Li, Y. Han, M. Luo et al., "Impact of megaproject governance on projectc performance: dynamic governance of 
the nanning transportation hub in China," Journal of Management in Engineering, vol. 35, no. 3, 2019.

[105] C.-H. Wang, The Moderating Role of Power Asymmetry on the Relationships between Alliance and Innovative Performance in the High-Tech industry, Technological Forecasting and Social Change, 2011. 